\title{
Discricionariedade administrativa e controle judicial
}

\author{
Wambert Gomes Di Lorenzo*
}

\section{INTRODUÇÃO}

Há uma invocação cotidiana e quase abusiva da expressão Estado de Direito feita pelo homem comum, pelas oposições políticas e pelos detentores do poder. Esse uso colaborou com um sentido mítico: a crença de que o reconhecimento como Estado de Direito legitima qualquer poder político.

Todavia, dentre tantas definições, aparece algo que é núcleo essencial em todas elas: liberdade e direitos fundamentais do cidadão a partir da limitação jurídica dos Estados e dos titulares do poder. O conceito de Estado de Direito só adquire sentido, inteligibilidade e justificação em função da garantia, do respeito e da promoção desses direitos e liberdades fundamentais.

A intervenção do Estado pode variar na sua intensidade e nas técnicas formais de sua limitação do Estado, mas só haverá Estado de Direito se, em seu cerne, estiver a preocupação de garantir e de proteger tais direitos. Essa é a natureza do Estado de Direito Liberal e a idéia que orienta o seu processo de racionalização. Essa racionalização irá surgir formalmente pela vitória da sociedade sobre o Estado e do Direito sobre o arbítrio. Para cumprir sua finalidade, este estabelece um sistema de garantias de natureza jurídica, a começar pela garantia dos direitos fundamentais e pela divisão de poderes.

Nesse contexto, os direitos fundamentais não devem ser considerados como um dos elementos do Estado, mas como verdadeiro fim da sua limitação jurídica. Para o Estado liberal, os direitos fundamentais são de natureza pré-estatais, cuja teorização global remonta a Locke.

\footnotetext{
-Advogado, professor na PUCRS, mestre em Direito do Estado e Teoria do Direito pela UFRGS e doutorando em filosofia do Direito na UFRGS.
} 
No confronto com o Estado absoluto, os direitos fundamentais surgem como direitos contra o Estado e como garantia da autonomia privada contra a intervenção do soberano. $O$ fator determinante dessa garantia estava no império da lei. A liberdade consistia em obedecer às Leis e não aos homens, pois democracia e liberdade significavam soberania da lei.

Do império da lei decorre o princípio da legalidade, que afirma o caráter soberano da função legislativa, quer na subordinação do executivo, quer na vinculação do judiciário. É, porém, com a relação entre executivo e legislativo que o Estado de Direito Liberal vai se preocupar. Sobretudo para subordinar a administração à lei.

Os interesses burgueses exigiam não somente subordinar politicamente o executivo ao parlamento, mas submeter a administração às leis. $\mathrm{Na}$ medida em que os direitos individuais eram sustentados pela lei que emanava do parlamento, a liberdade e a propriedade burguesas só estariam garantidas mediante a submissão da administração ao espírito dessa lei.

No conceito acima, tem-se o Estado de Direito Material, já que a limitação jurídica do poder se justifica em função da garantia de um núcleo de valores considerado indisponível pelo próprio Estado. Baseando-se nessa idéia particular de direito e de justiça material é que a burguesia rompeu com o antigo regime.

Entretanto, para considerar como dimensão exclusiva ou determinante da racionalização do Estado, essas técnicas de garantia daqueles direitos fundamentais configuram-se como valores autônomos. Com isso, o conceito de Estado de Direito surge, cada vez mais, identificado com os seus elementos formais-instrumentais, principalmente $o$ princípio da legalidade da administração e da justiça administrativa.

Todo esse entendimento sobre Estado de Direito, mais modernamente acrescido do princípio democrático, levanta-se contra a discricionariedade ou o mérito administrativo, aqui entendido como um sanctus sanctorum do Estado onde o poder judiciário não pode penetrar.

À contramão do direito continental e da própria doutrina francesa, que evoluiu, o direito brasileiro se mantém isolado na idéia de "administração forte", que predominava na França na primeira metade do século XX. Isso se dá, sobretudo, pela manutenção de uma divisão tripartite estanque e superada, na qual um único poder concentra as funções de chefia do Estado, chefia do governo e administração pública. É uma simbiose institucional que impede a jurisprudência de encontrar a tênue linha que separa o poder político da função burocrática.

Dessarte, este trabalho está dividido em duas partes. Na primeira, pretende apresentar um conceito de discricionariedade partindo da idéia de poder discricionário, perpassando pela Teoria Geral do Direito, ao visitar a relação entre Discricionariedade Administrativa e os conceitos jurídicos 
indeterminados, deduzindo daí a própria idéia de ato. Na segunda parte, trabalha a idéia do controle do ato a partir dos seus vícios, sob o prisma da legalidade, da idéia de mérito, da distinção entre o político e o administrativo para inferir a idéia de discricionariedade em face dos direitos subjetivos e do princípio da tutela e do monopólio.

\section{UM CONCEITO DE DISCRICIONARIEDADE}

\subsection{Do poder discricionário}

Apesar da exaustiva abordagem do tema pela doutrina, parece-me que nossos sistemas científicos necessitam de um enfoque mais factual no que diz respeito ao tema, voltado para os fenômenos específicos do nosso direito público. Também a jurisprudência corrobora com tal equívoco, porquanto constrói um raciocínio divorciado do nosso ordenamento jurídico.' Reservada essa discussão para a segunda parte, é bem verdade que à jurisprudência é dada a tarefa de preencher as normas vagas. Entretanto, ela pouco tem aplicado a real proporcionalidade na acomodação dos princípios, como também tem demorado a adequar seu entendimento à ratio legis da atual
Constituição e ao Estado Democrático de Direito, ainda carente de concreção.

Todavia, o caminho jurisprudencial é inevitável na construção de um conceito de discricionariedade. Se a doutrina se perde por não construir um pensamento mais fenomênico, vem o judiciário na aplicação da norma particular, edificando uma idéia própria, mesmo que imóvel perante a evolução do direito constitucional positivo.

Para cumprir sua função, a administração é dotada de poderes, dentre eles o discricionário. Esses poderes se distinguem dos poderes políticos, pois dizem respeito à atividade do Estado, em sua função burocrática, na tarefa de atender o cidadão e a sociedade, e à ação específica do Estado através dos seus organismos administrativos. Os poderes administrativos são mecanismos, isto é, ferramentas que possibilitam à burocracia cumprir o seu papel com eficiência; são, no entendimento de Hely Lopes Meirelles, poderes instrumentais que divergem dos políticos, uma vez que se referem à estruturação do próprio Estado. ${ }^{2}$

Michel Stassinopoulos ${ }^{3}$ sintetiza as definições das principais escolas: a primeira define como discricionariedade

\footnotetext{
1 No conceito de Canaris, que classifica os sistemas em científico (doutrina) e objetivo (ordenamento jurídico). A doutrina tem a tarefa de socorrer o sistema objetivo na provisoriedade do seu conhecimento (Cf. CANARIS, Claus-Wilhelm. Pensamento Sistemático e Conceito de Sistema na Ciência do Direito. Lisboa: Fundação Calouste Gulbenkian, 1989).
}

2 Direito Administrativo Brasileiro.24. ed. São Paulo: Malheiros, 1999, p. 101.

3 Traité des Actes Adminstratifs. Atenas, 1954. 
a determinação ou a capacidade de determinação de um conteúdo deixado impreciso pela norma; outra afirma ser tudo aquilo que excede aos limites fixados pela norma, que podem ser protegidos como direito subjetivo; uma terceira diz ser todo aquele poder que escapa do controle jurisdicional; a quarta coloca a possibilidade de escolha como fundamento da discricionariedade; outra coloca no cerne da ação discricionária a motivação.

A discricionariedade é a faculdade concedida à administração de eleger o objeto e a forma do ato, quando não estabelecido em lei. ${ }^{4}$ É, segundo Almiro do Couto e Silva, a escolha do se e do como da ação. ${ }^{5}$ Ela dá ao administrador a liberdade de praticar ou não praticar um ato, como também de escolher a forma de agir para atingir a finalidade administrativa. A escolha de ação ou omissão do ato, configura a discricionariedade mínima e expressa a impossibilidade de desvincular o poder discricionário da lei. A faculdade de agir ou não agir significa que mesmo a liberdade de escolha subsume na legalidade, pois é a lei, e não o arbítrio do agente, que determina esta margem de decisão.
Mesmo que a liberdade de escolha seja ampliada, esta estará sempre adstrita à lei que determinará o nível de amplitude da liberdade de decidir.

Assim, falha a definição de discricionariedade que parte da antinomia de vinculação:

O conceito de poder discricionário só tem sentido e só adquire expressão prática quando posto em contraste com outras situações em que o agente do Estado tem o dever jurídico de atuar ou de omitir-se e pode ser compelido a isso. ${ }^{6}$

Tendo em vista a existência de poder discricionário também nas funções legislativa e judiciária, a idéia acima diz respeito exclusivamente à discricionariedade legislativa, porquanto, segundo o magistério de Almiro do Couto e Silva, o legislador não tem competência vinculada. ${ }^{7}$ Tal entendimento encontra oposição em Kelsen, que afirma que a validade de uma norma, inclusive constitucional, sempre terá seu fundamento em uma Norma Fundamental. Assim, também o processo legislativo e o conteúdo das normas produzidas, ou seja, o poder de legislar, seria poder vinculado e não discricionário. ${ }^{8}$

4 TÁCITO, Caio. O abuso do poder administrativo no Brasil (conceito e remédios). DIN - Serviço de Documentação do DASP, Rio de Janeiro, p. 30.

5 Cf. COUTO E SILVA, Almiro. Poder discricionário no direito administrativo Brasileiro. Revista de Direito Administrativo, Rio de Janeiro, n. 179, p. 51-92, jan-jun/1990. p. 55. 6 COUTO E SILVA. Id., ibidem.

7 Id., ibid.

8 Sobre a idéia da Norma Fundamental em Kelsen, Cf. BARZOTTO, Luis Fernando. $O$ Positivismo Jurídico Contemporâneo (Uma introdução a Kelsen, Ross e Hart). Porto Alegre: Unisinos, 1999. p. 40-43. 
Vale-se da antinomia Celso Antônio Bandeira de Mello, inicialmente, para classificar atos vinculados e discricionários quanto ao grau de liberdade da Administração em sua prática. ${ }^{9}$ Posteriormente, para defini-los a partir da oposição conceitual. ${ }^{10}$

Convém distinguir a discricionariedade na função judiciária. Essa ocorre de duas maneiras: primeiro, de forma estrita, quando o juiz engasta o fato na previsibilidade normativa; segundo, quando se trata das normas vagas (princípios, cláusulas gerais ou conceitos indeterminados) que devem ter seu conteúdo preenchido valorativamente pela jurisprudência.

Dessarte, não há de se falar de discricionariedade administrativa como desvinculação da lei, ou mesmo como válvula da rigidez da legalidade, na expressão de Tércio Sampaio Ferraz Júnior. ${ }^{11}$ Como afirma Gordillo:

A discricionariedade não é o resultado de uma carência pura e simples de regulamentação normativa: é em realidade uma forma possível de regulamentação, na qual a lei fixa um marco de competência dentro do qual deixa ao funcionário certa margem de decisão, de criação própria, sem que isto signifique, por si só, que a mera atribuição de competência possa entender-se como outorga de liberdade para atuar..$^{12}$

Assim, podemos afirmar que a discricionariedade administrativa é uma atribuição de competência conferida pelo direito, um poder limitado atribuído pelo legislador.

A expressão poder discricionário tem uso majoritário na doutrina nacional. Ela é coerente com o nosso superado sistema tripartite que delega a um único poder três funções: a chefia do Estado, o governo e a burocracia. Tal realidade, como veremos na seqüência, é um dos obstáculos do controle jurisdicional, pois tarefa difícil é localizar a tênue linha que separa o poder político da função administrativa quando exercida pela mesma pessoa. A doutrina alemã distingue administração de governo. ${ }^{13}$ Enquanto este tem função política, a burocracia é apolítica e não exerce função autônoma. Ao governo é conferido poder discricionário, mas não à

9 BANDEIRA DE MELLO, Celso Antônio. São Paulo: Malheiros, 1997. p. 262. 10 Id., ibid., p. 266.

11 A Relação Meio/Fim na Teoria Geral do Direito Administrativo, in RDP, 61/27. Apud GRAU, Eros Roberto. Poder Discricionário. Revista de Direito Público, Rio de Janeiro: $\mathrm{n}^{\circ}$ 93, p. 41-46, jan-mar/1990. p. 41.

12 GORDILlO, Agustín. Princípios Gerais de Direito Público (Trad. De Marco Aurélio Greco). São Paulo: Revista dos Tribunais, 1977. p. 170.

13 Tal distinção também se encontra em Hely Lopes Meirelles, op. cit., p. 100. 
administração. ${ }^{14} \mathrm{O}$ mesmo ocorre com a doutrina francesa, que afirma não existir jamais, para a administração, um poder discricionário. Porque não lhe é nunca deixado poder de livre apreciação quanto ao fim a alcançar. ${ }^{15}$

À burocracia é dada a tarefa de agir buscando a utilidade pública em nome do Estado. Para tanto, o legislador a instrumentaliza com mecanismos necessários à sua eficiência, a essas ferramentas a doutrina dá o nome de poderes administrativos. Dentre eles, está o poder discricionário que, escusando-me pela tautologia, nada mais é que a capacidade de agir com uma certa liberdade determinada previamente pelo ordenamento jurídico. Poder discricionário é uma delegação de competência dada pelo Estado à burocracia.

Trata-se de um poder-dever, na expressão de Eros Roberto Grau. ${ }^{16}$ Também Hely Lopes Meirelles afirma não ser possível distinguir o que vem a ser poder ou dever da administração. ${ }^{17}$ Na verdade, é para o administrador um dever de agir e não mera faculdade como seria para um particular. Tratase, então, de um meio e não de um fim em si mesmo. ${ }^{18}$

Vale ressaltar que é equivocada a expressão poder arbitrário, já utilizada por nossa jurisprudência constitucional: Há que distinguir entre poder discricionário e poder arbitrário. ${ }^{19}$ A arbitrariedade é o não-direito, a insurreição contra o ordenamento jurídico, contra o Estado que o estabeleceu e a sociedade que o legitima. Poder é uma delegação de competência dada pelo Estado, uma função estatal que subsume no princípio da legalidade, pressuposto do Estado de Direito. Tais conceitos colocam uma separação abissal e definitiva entre as noções de arbitrariedade e discricionariedade.

\subsection{Discricionariedade admi- nistrativa e conceitos jurídicos indeterminados \\ Uma doutrina majoritária assevera que a discricionariedade advém dos conceitos juridicos indetermi- nados. ${ }^{20}$ Outra afirma haver, na área}

14 Cf. HESSE, Konrad. Elementos de Direito Constitucional da República Federal da Alemanha (Grundzüge des Verfassungsrechts der Bundesrepublik Deutschland). (Trad. Luís Afonso Heck) Porto Alegre: Fabris, 1998. p. 404.

15 Cf. BONNARD, Roger. Précis de Droit Adminstratif. Paris: 1935 e 1940, apud Hely Lopes Meirelles. Op. cit., p. 152.

16 Poder Discricionário. Revista de Direito Público, n. 93, p. 41-46, jan-mar/1990. p. 41.

17 Op. cit., p. 89.

18 Id., ibid., p. 152.

19 Recurso Extraordinário 68388/SP. $1^{\text {a }}$ Turma, j. 11/11/1969. Rel. min. Luís Callotti. DJU 24/04/1970. Ementa.

20 Eros Roberto Grau afirma inexistir conceitos como tais indeterminados. Todo conceito é produto da reflexão, expressando uma suma de idéias. Quando expressado, através do seu termo, envolve um ato de expressão. O termo, pois, é a expressão do conceito (Op. cit., p. 42). 
de livre apreciação, um ponto em comum entre os dois. ${ }^{21}$ Adotada a primeira posição, afirmamos que a processão da discricionariedade administrativa diz respeito às Regras Gerais (conceitos jurídicos indeterminados e cláusulas gerais) e não às normas vagas como um todo.

Acatando a distinção entre princípios e regras afirmada por Dworkin, entendemos que os princípios conferem discricionariedade lato sensu, por serem standarts juridicamente vinculantes radicados na idéia de justiça, fundamentos das normas e normas bases que constituem a ratio das regras. ${ }^{22}$ Além disso, a vagueza conceitual dos princípios deverá ser preenchida exclusivamente pelo judiciário.

Três são as espécies de normas vagas: os princípios, as cláusulas gerais e os conceitos jurídicos indeterminados. Dessas, as duas últimas podem ser consideradas Regras Gerais, não obstante contrário pensamento da maior parte da doutrina. Entendo, de acordo com os ensinamentos de Judith MartinsCosta, haver distinção entre as cláusulas gerais e os conceitos jurídicos indeterminados. ${ }^{23}$
Apenas dessas Regras Gerais advém a discricionariedade administrativa, sobretudo por serem regras dirigidas ao intérprete que, excepcionalmente, pode não ser o judiciário, como é o caso das regras administrativas.

Como afirmamos, juntamente com os princípios, essas são espécies de normas vagas, sempre dirigidas ao intérprete, que descrevem uma conduta de forma aberta sem determinar claramente suas consequiências e sem pretender prever todos os problemas da realidade, dando-lhes respostas prévias. São meios e técnicas de recepção e concreção dos princípios. ${ }^{24}$ Elas não pretendem tipificar condutas e determinar suas conseqüências. Diferentemente, pela vagueza semântica, estão abertas a conceitos que lhe darão conteúdo, utilizando enunciados vagos na configuração da fattispecie. ${ }^{25}$

São normas que forçam o intérprete a uma medida própria de valoração. Para Canaris, uma de suas características é estar carecida de preenchimento com valorações, isto é, o ela não dar os critérios necessários para a sua concretização. ${ }^{26}$

21 Sobre a evolução histórica deste conceito: Cf. COUTO E SILVA, Almiro. Op. cit., p. 57. 22 Cf. DWORKIN, Ronald. Los derechos en serio. Barcelona: Ariel, 1999. p. 72-80.

23 MARTINS-COSTA, Judith. A boa-fé no Direito Privado: sistema e tópica no processo obrigacional. São Paulo: Revista dos Tribunais, 1999, p. 324-328.

24 Cf. DI LORENZO, Wambert Gomes. As Cláusulas Gerais como técnica de recepção, no Direito Privado, das normas constitucionais. No prelo.

25 Base ou suporte fático.

26 Op. cit., p. 142. 
Menezes Cordeiro ${ }^{27}$ divide-as em três espécies: restritivas, regulativas e extensivas. Restritivas, por delimitarem ou restringirem um conjunto de permissões oriundas de regras e princípios jurídicos; regulativas, porque regulam hipóteses, com base em um princípio; e, extensivas, por ampliarem determinada regulação jurídica mediante expressa possibilidade de introdução de princípios e regras próprias de outros textos normativos.

Qualquer norma jurídica, como tal, deverá estar estruturada em duas partes: suporte fático e conseqüência jurídica. Kelsen afirma que o suporte fático se refere a uma conduta humana. Tal conduta é o objeto da própria norma. ${ }^{28}$ A norma pode, eventualmente, referir-se a algo diferente dessa conduta ou mesmo de seus efeitos. Todavia, para que a norma tenha validade, o suporte fático deverá ser exeqüível. ${ }^{29} \mathrm{~A}$ conseqüência deve ser, também, exeqüível, pois, se ela é impossível, torna a norma inválida.

Tal raciocínio tem aplicação conforme a função pretendida pela norma, pois diz respeito exclusivamente às normas primárias. Todavia, também nas normas secundárias, a conseqüência jurídica se refere a uma conduta. Isso se dá pela diversidade de funções que a norma assume, que Kelsen divide em imposição, permissão, autorização e derrogação. ${ }^{30}$

Apesar da clara distinção entre as funções das normas secundárias, a autorização pode implicar imposição. Isso ocorre quando ela autoriza o estabelecimento da norma particular pelo aplicador. ${ }^{31}$ É precisamente o caso da norma administrativa, que oferece um suporte fático impreciso que deve ser estatuído pelo administrador. Ressalta-se que não é uma delegação de arbitrariedade.

O Tribunal Constitucional Alemão afirma que as Regras Gerais são fundamentais para o direito administrativo porque a multiplicidade das tarefas econômicas nem sempre se deixa apreender em conceitos de contornos claros. Neste campo, o legislador não pode abrir mão de tais regras, mas se servirá delas para colocar instrumentos eficientes nas mãos do administrador. ${ }^{32}$

27 Cf. Da Boa Féno Direito Civil, Tomo II. p. 1184. Apud MARTINS-COSTA, op. cit., p. 295. 28 Cf. KELSEN, Hans. Teoria Geral das Normas. Porto Alegre: Fabris, 1986. p. 39.

29 Kelsen se trai por admitir a eficácia como pressuposto de validade da norma. Sobre uma crítica ao positivismo kelseniano, Cf. BARZOTTO. Op. cit., p. 62-71.

30 Cf. KELSEN, op. cit., p. 130.

31 Cf. KELSEN, op. cit., p 131.

32 Cf. HECK, Luís Afonso. O tribunal Constitucional Federal e o desenvolvimento dos principios constitucionais: Contributo para uma compreensão da Jurisdição Constitucional Federal Alemã. Porto Alegre: Fabris, 1995. p. 207. 
As Regras Gerais apresentam a mesma estrutura bipartite elementar de todas as normas. Porém, é no seu suporte fático que está a diferença da norma casuística. Enquanto a fattispecie da casuística é precisa, nítida, nas Regras Gerais, o que predomina é uma ratio dicidendi, baseada em critérios que podem ser metajurídicos, como, por exemplo, na chamada discricionariedade técnica. Esse suporte fático impreciso leva Karl Engish $^{33}$ a afirmar que as Regras Gerais não possuem qualquer estrutura própria. Cláudio Luzzati ${ }^{34}$ assevera que são normas parcialmente em branco.

Eros Roberto Grau distingue conceitos indeterminados de poder discricionário. Segundo ele, os conceitos indeterminados restringem a uma única solução, enquanto que o poder discricionário admite várias soluções justas. Opõe os conceitos, afirmando ser a discricionariedade uma liberdade de eleição, enquanto a aplicação de conceitos indeterminados é um caso de aplicação da lei. ${ }^{35}$ Tal contradição leva a concluir que se trata de um poder arbitrário que deserta da legalidade.

Hesse, tratando de vinculação administrativa, afirma que o poder administrativo é vinculado mesmo lá onde as normalizações vinculativas são indeterminadas e amplamente formuladas e, com isso, põe aos órgãos da administração a tarefa da concretização relacionada ao caso. ${ }^{36}$ Também a jurisprudência alemã afirma que o legislador não deve fazer uso de Regras Gerais para deixar a decisão sobre a liberdade dos cidadãos unilateralmente à discrição da administração. ${ }^{37}$

\subsection{Do ato discricionário}

Se a discricionariedade administrativa é potência, significa que, como tal, não passa de uma capacidade de

33 Introdução ao pensamento jurídico, p. 190. Apud MARTINS-COSTA, Judith. O Direito Privado como um "Sistema em construção" - As Cláusulas Gerais no projeto do Código Civil Brasileiro. Revista dos Tribunais, São Paulo: v. 753, p. 24-28, jul. 1998.

$34 \mathrm{Cf}$. La vaghezza delle norme - un'analise del linguaggio giuridico. Milão: Giuffrè, 1990, p. 414.

35 In verbis: "a aplicação dos conceitos indeterminados só permite uma única solução justa. Contrariamente, o exercício da potestade discricionária permite uma pluralidade de soluções justas ou, em outros termos, optar entre alternativas que são igualmente justas desde a perspectiva do Direito. Daí por que a discricionariedade é essencialmente uma liberdade de eleição entre alternativas igualmente justas ou entre indiferentes jurídicos, ao passo que a aplicação de conceitos indeterminados é um caso de aplicação da lei" (Poder Discricionário, p. 42).

36 HESSE, Konrad. Elementos de Direito Constitucional da República Federal da Alemanha (Grundzüge des Verfassungsrechts der Bundesrepublik Deutschland). (Trad. Luís Afonso Heck). Porto Alegre: Fabris, 1998. Grifo meu.

37 Cf. HECK, Luís Afonso. Op. cit., p. 206. 
agir do administrador conferida pelo legislador. Para migrar do mundo ideal para a realidade concreta, essa potência necessita do ato. Ato, de uma forma genérica, é a maneira de como um ens (ser) passa a existir. É ele que vai dar existência ao ens, tornando-o um esse (ser existencial).

Poder, nada mais é que a simples aptidão para a existência. O ser é porque existe. Poder, si per si, não é ser mas dever ser. Para se definir quod est (como o que é), ou, como afirmou Santo Tomás, res habens esse (uma coisa possuindo a existência), ${ }^{38}$ ele precisa realizar seu actus essendi. (ato de ser).

É o ato administrativo que permite ao poder seu actus essendi (ato de existir). Todavia, para configurar a real existência de um poder, ele tem sua forma estritamente definida pela lei. Todo o ato tem seus elementos fundamentais, o ato discricionário tem elementos constitutivos próprios.

$\mathrm{O}$ ato administrativo, segundo a doutrina francesa, define-se como aquele praticado por um órgão administrativo do Estado, devendo-se distingui-lo de uma parte dos outros órgãos de Estado, legiferantes e jurisdicionais e de outra parte dos organismos privados. ${ }^{39}$

No direito alemão, a definição de ato administrativo, bem como de seus elementos constitutivos, encontra-se no $\S 35$ da lei do procedimento administrativo da República Federal e nas leis de procedimento administrativo dos estados-federados individuais. Segundo a norma maior, um ato administrativo é cada ordem ou outra miedida soberana no direito público que parte de uma autoridade para regular um caso particular e que está ajustada para produzir efeitos externos jurídicos. ${ }^{40}$ A norma apresenta-nos, ainda, seis definições: medida, autoridade, direito público, regulação, caso particular e efeito externo. ${ }^{41}$

Celso Antonio Bandeira de Mello ressalta a diferença entre atos administrativos e atos da administração. Entretanto, o critério sugerido pelo autor é de uma classificação segundo a importância, excluindo, assim, atos que não interessa considerar como atos administrativos. ${ }^{{ }^{2}}$ Ato administrativo, entende o autor, são declarações do

38 Cf. AQUINO, Santo Tomás de. In Peih, I, lect. 5, Leonina. Apud JOLIVET, Régis. Tratado de Filosofia-Metafisica. Rio de Janeiro: Agir, 1972, p.198.

39 Cf. LAUBADÈRE, André de; VENEZIA, Jean-Claude; e GAUDEMET, Yves. Traité de Droit Administratif. 14.ed. Paris: L.G.D.J. Tome 1, p. 575.

40 MALLMANN, Dankwart. Elementos de formação do ato administrativo no direito alemão. (Trad.Luís Afonso Heck). Estudos Jurídicos, Porto Alegre: v. 31, n. 81, p. 95-103, jan-abr/1998. 41 Id., ibid.

42 BANDEIRA DE MELLO. Op. cit., p. 229. 
Estado, no exercício de prerrogativas públicas, manifestadas mediante providências jurídicas. ${ }^{43} \mathrm{Ou}$, ainda, declaração unilateral do Estado no exercício de prerrogativas públicas, manifestada mediante comandos concretos complementares da lei..$^{44}$

Defino, entretanto, ato administrativo como toda aquela ação administrativa que surte efeito jurídico. Para surtir efeito jurídico, o ato precisa ser válido e eficaz, obedecendo à forma legal e alçando o fim pretendido. Deve seguir com precisão a lei tanto na sua forma, quanto no seu conteúdo, como também na sua motivação e finalidade. Qualquer desvinculação desses pontos à lei, torna o ato inválido. ${ }^{45} \mathrm{~A}$ doutrina predominante na Alemanha considera o efeito jurídico para determinar a existência do ato, em alguns casos, apenas se há uma perda de direito. É o caso do exemplo levantado por Mallmann dos atos de graça. Eles não devem ser considerados atos administrativos, pois escapam ao direito já que à graça ${ }^{46}$ ninguém tem um direito (cita como exemplo a libertação prematura de um preso). Já a revogação da graça é um ato administrativo, pois, por meio dela, o preso perdeu um direito.

Parte da doutrina nacional se opõe à expressão ato discricionário. Victor Nunes Leal afirma que não se deve falar de ato discricionário, mas de poder discricionário da administração. Pois que a discricionariedade não se manifesta no ato em si, mas no poder da administração. ${ }^{47}$ Segundo Lopes Meirelles, atos discricionários são aqueles que a Administração pode praticar com liberdade de escolha de seu conteúdo, de seu destinatário, de sua conveniência, de sua oportunidade e de seu modo de realização. ${ }^{+8}$

Diria, portanto, que atos discricionários são a forma de agir da administração que dá concreção ao poder discricionário.

Recorrendo à jurisprudência do STF, encontramos os elementos constitutivos dos atos discricionários:

Ato discricionário está fundado em juízo de conveniência e

\section{Id., ibid.}

44 Id., ibid., p. 232.

45 Assim entendeu o STF: "Os atos administrativos não podem ser revogados, mesmo quando discricionários, se deles nasceu um direito público subjetivo, salvo se o ato não obedeceu à lei. Porque então, já não se trata de revogação, mas de anulação, com efeitos ex tunc, pois do ato nulo, em regra não nasce direito (Recurso Extraordinário 51680. $1^{\mathrm{a}}$ Turma, j. 18/04/1963. Rel. min. Luís Gallotti. DJU 18/04/1963. Ementa.) Grifo meu.

46 Graça significa mercê, benefício ou dádiva. Vem do latim gratia que por sua vez deriva do grego chári: favor, dom, dádiva, presente.

47 Cf. LEAL, Victor Nunes. Poder discricionário e ação arbitrária da administração. RDA 14/53, apud MEIRELLES, Hely Lopes. Op. cit., p. 150.

48 Op. cit., 150. 
oportunidade do Poder Público, destina-se, a partir de critérios racionais-lógicos e impessoais estabelecidos de modo legítimo em norma legal, implementar objetivos estatais nitidamente qualificados pela nota da extrafiscalidade. ${ }^{49}$

Os elementos constitutivos corroboram a afirmação anterior de que discricionariedade e arbitrariedade não se confundem. A liberdade de agir tem limites. Não pode ser um ato do administrador que fira a legalidade, que seja inconveniente, inoportuno, ou mesmo que não tenha racionalidade ou razoabilidade.

A discussão, ora, é obstaculizada pela questão do mérito, que diz respeito diretamente aos elementos constitutivos. É em torno do controle judicial dos atos discricionários e da existência de um mérito administrativo, como um ente sagrado e intocável, que se deve construir uma definição precisa e toda particular de discricionariedade, como também de seus elementos constitutivos.

\section{O CONTROLE JUDICIAL}

\subsection{Os vícios do ato}

Como vetor de existência de uma potência, o ato, para também existir como tal, precisará ser válido e eficaz, ou seja, estar coerente com o sistema jurídico a que pertence e resultar os efeitos jurídicos pretendidos. Ele segue a forma da lei e subsume no Estado de Direito e no Princípio da Legalidade.

A doutrina entende que $o$ ato pode fugir da forma legal ou não cumprir sua finalidade: são os vícios do ato. Quanto aos vícios do ato discricionário, Almiro do Couto e Silva classifica-os em três espécies: transgressão dos limites do poder discricionário, abuso ou desvio do poder discricionário e não-exercício ou exercício deficiente do poder discricionário. ${ }^{50}$ Segundo o mesmo magistério, dos dois primeiros decorrerá a absoluta invalidade, enquanto que o terceiro poderá dar causa à anulação do ato, sendo que, para tanto, o error juri é irrelevante e o error facti é fator de nulidade.

Para Themístocles Cavalcanti, o abuso e o desvio de poder são os principais vícios do ato discricionário. Abuso de poder é aquela ação exercida contrariando a lei ou extrapolando os limites por ela fixados. Desvio de poder é uma idéia oriunda do Conselho de Estado da França e diz respeito diretamente à competência. $\mathrm{Na}$ verdade, o vício de competência é essencialmente um abuso de poder. ${ }^{51}$

49 Agravo 142348/MG. 1ª Turma, j. 02/08/94. Rel. min. Celso de Mello. DJU 24/03/95. Ementa. Grifo meu.

50 Cf. COUTO E SILVA, Almiro. Poder discricionário no direito administrativo brasileiro. Revista de Direito Administrativo, Rio de Janeiro: n. 179, p. 51-92, jan-jun/1990, p. 63. 51 CAVALCANTI, Themístocles Brandão. Do poder discricionário. Revista do Direito Administrativo, Rio de Janeiro: n. 101, p. 1-23, jul-set/1970. p. 13. 
Celso Antônio Bandeira de Mello define desvio de poder como a utilização de uma competência em desacordo com a finalidade que lhe preside a instituição. ${ }^{52}$ Para ele, o desvio de poder é um dos mais graves vícios do ato administrativo. Afirma, ainda, que, na sua totalidade, os vícios são vícios de competência. ${ }^{53}$ Hely Lopes também fala de abuso de poder como ultrapassagem dos limites da atribuição e desvio da finalidade. ${ }^{54}$

Um outro elemento constitutivo do ato é a motivação. Ela nem sempre é exigida pela lei, entretanto, se formalmente mencionada, vincula ação administrativa. ${ }^{55} \mathrm{~A}$ motivação só cabe nos atos discricionários, porquanto os vinculados têm, na lei, o seu motivo de agir. Assim, a motivação traz a discricionariedade para a esfera do controle judicial: $O$ controle judicial só se exerce sobre o ato administrativo motivado. Caso em que a lei exige motivo mas não a sua comprovação. ${ }^{56}$

\subsection{Ato e legalidade}

De qualquer maneira, o ato deve satisfazer as exigências da legalidade. É nela que o Estado Democrático de Direito vai buscar sua própria definição, como acrescenta Canotilho:

O princípio da legalidade da administração, sobre o qual insistiu sempre a teoria do direito público e a doutrina da separação dos poderes, foi erigido, muitas vezes, em 'cerne essencial' do Estado de Direito. Postulava, por sua vez, dois princípios fundamentais: o princípio da supremacia ou prevalência da lei (Vorrang des Gesetzes) e o princípio da reserva da lei (Vorbehalt des Gesetzes). ${ }^{57}$

A rigor, no aspecto jurídico, todo Estado é de Direito. É a teoria da bilateralidade ou da autovinculação, na qual o Estado cria um direito para depois se submeter a ele, tese com a qual concorda Kelsen: $O$ Estado deve ser apresentado como pessoa diferente do direito para que o direito possa iustificar o Estado. ${ }^{58}$

52 BANDEIRA DE MELLO, Celso Antônio. Desvio de poder. Revista de Direito Público, Rio de Janeiro: n. 89, p. 24-36, jan./mar. 1989, p.13.

53 Id., ibid., p. 29.

54 Cf. MEIRELLES, Hely Lopes. Direito Administrativo Brasileiro. 24. ed. São Paulo: Malheiros, 1999, p. 95.

55 Cf. STF Recurso em Mandado de Segurança 17807/PE. $2^{\text {a }}$ Turma, j. 06/03/1968. Rel. min. Themístocles Cavalcanti. DJU 28/06/1968: $O$ exame dos motivos do ato administrativo, só se pode verificar no caso em que a lei exige a sua comprovação e o ato é motivado (voto do Relator).

56 STF. Recurso de Mandado de Segurança 16807/PE. 2a Turma, j. 06/03/68. Rel. min. Themístocles Cavalcanti. DJU 26/06/68. Ementa.

57 CANOTILHO, J. J. Gomes. Direito Constitucional e Teoria da Constituição. Coimbra: Almedina, 1998, p. 249.

58 KELSEN, Hans. Teoria Pura do Direito.3. ed. São Paulo: Martins Fontes, 1991. p.301. 
É a legalidade que concede validade e eficácia ao ato. A própria eficácia tem seu fundamento na lei, ${ }^{59}$ que vincula não apenas a forma, mas, também, o objeto do ato. ${ }^{60}$

A jurisprudência tem limitado à legalidade o exame do ato discricionário:

Limites do poder discricionário. Os atos do poder público, além de sujeitos aos princípios da legalidade e da moralidade, também devem atender a princípio de justiça. ${ }^{61}$

Definida a legalidade, resta dizer que moral e justo, no que diz respeito à administração, é o rigoroso cumprimento da lei. A idéia de justiça na adıninistração não admite conceitos metajurídicos, ocorrendo o mesmo com a moral administrativa que é uma espécie de 'autolimitação', uma limitação nascida da própria administração e vinculativa de seus agentes, e não uma heterolimitação da própria Administração. ${ }^{62}$

\subsection{A idéia de mérito}

Entretanto é na conveniência e na oportunidade que se encontra o que boa parte da doutrina chama de zona livre. Uma área impenetrável pela jurisprudência: $E$ ato discricionário que escapa ao controle do Poder Judiciário e envolve juízo de conveniência e oportunidade do poder Executivo. ${ }^{63}$

Essa área inacessível ao judiciário é delimitada pela conveniência e pela oportunidade. Para a administração, o iusto manifesta-se pelo legal, e a legalidade não escapa ao controle judicial. A doutrina é unânime ao referirse a essa zona como mérito administrativo que, como vimos, a jurisprudência tem se isentado de apreciar.

Seabra Fagundes afirma que $o$ merecimento é aspecto pertinente apenas aos atos administrativos praticados no exercicio de competência discricionária. ${ }^{64}$

Em desconformidade com a jurisprudência brasileira, o Tribunal Constitucional da República Federal da

59 Cf. SILVA, José Afonso da. Op. cit., p. 110.

60 Cf. MEIRELLES, Hely Lopes. Op. cit., p. 185.

G1 STI. Recurso Extraordinário 173820/DF. 2ª Turma, j. 18/06/1996. Rel. min. Néri da Silveira. DJU 13/09/1996.

62 MODESTO, Paulo. Controle jurídico do comportamento ético da administraçào pública no Brasil. Revista do Direito Administrativo, Rio de Janeiro: n. 209, p. 71-80, jul-set/1997, p. 73.

63 STF. Recurso Extraordinário 188951/SP. $2^{\mathrm{a}}$ Turma,j. 16/05/95. Rel. min. Maurício Correia. DJU 15/09/95. Ementa. Grifo meu.

64 O conceito de mérito no Direito Administrativo. Apud MEIRELLES. Op. cit., p. 137. 
Alemanha adentra no mérito eficácia do direito. ${ }^{67}$ No ensinamento administrativo a partir da proibição de arbitrariedade. Segundo a jurisprudência alemã, a arbitrariedade pode ocorrer não apenas na decisão, mas também nos elementos de formação e desenvolvimento do ato. ${ }^{65}$

A majoritária doutrina nacional tem afirmado que não há mérito inapreciável. ${ }^{66}$ Segundo Eros Roberto Grau, o mérito significa adequação do ato a sua finalidade e essa adequação deve, necessariamente, ser objeto de controle jurisdicional, até porque é na medida em que opere o Poder Judiciário que se poderá avaliar a de Hely Lopes Meirelles, mérito diz respeito aos elementos não vinculados que admitem uma valoração de eficiência, oportunidade, conveniência e justiça ${ }^{68}$ Segundo ele, tais elementos podem ser revistos e o ato anulado se, por trás da discricionariedade, estiver o abuso ou o desvio de poder. ${ }^{69}$

Trata-se de uma escolha entre duas posições confrontantes acerca do Direito administrativo: ex parte principe ou ex parte populi. ${ }^{70} \mathrm{~A}$ primeira trata de um direito privilegiado do Estado sobre o cidadão. Era o direito vigente no Estado de Polícia, segunda fase histórica do absolutismo."1

65 Cf. HECK, Luís Afonso. O Tribunal Constitucional Federal e o desenvolvimento dos princípios constitucionais: Contributo para uma compreensão da Jurisdição Constitucional Federal Alemã. Porto Alegre: Fabris, 1995, p.229.

66 Em sentido contrário. Cf. FERREIRA FILHO, Manoel Gonçalves. Poder judiciário na Constituição de 1988 (Judicialização da política e politização da justiça). Revista de Direito Administrativo, Rio de Janeiro: $\mathrm{n}^{\circ} 189$ p. 1-17, out-dez/1994.

67 GRAU, Eros Roberto. Poder discricionário. Revista de Direito Público, Rio de Janeiro: $\mathrm{n}$. 93, p. 41-46, jan-jun/1990, p. 63.

68 Cf. nota 48.

69 Op. cit., p. 138.

70 Cf. MODESTO, Paulo. Controle jurídico do comportamento ético da administração pública

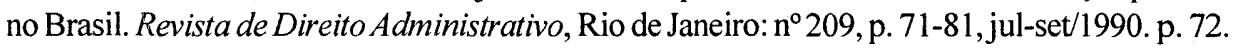
71 À primeira fase do absolutismo deu-se o nome de Estado Patrimonial, no qual o Estado era considerado um bem patrimonial do príncipe. Em ambas as fases a vontade arbitrária do príncipe prevalecia em face das possibilidades de defesa judicial dos particulares. Além da responsabilidade pessoal dos funcionários por atos ilícitos (dificilmente exeqüível) os particulares não tinham qualquer mecanismo de defesa contra o Estado. No Estado de Polícia ressurge a doutrina do Fiscus (oriunda do Direito Romano), onde o Estado (que até então estava à margem do direito e fora do controle judicial) se desdobrava numa outra pessoa moral, com capacidade jurídica ativa e passiva, capaz de se obrigar contratual e extracontratualmente. Distinguindo-se portanto os bens do Fisco dos bens do príncipe. A doutrina do Fisco entretanto, garantia apenas os danos patrimoniais, não entrando na esfera autônoma dos direitos particulares. O estado permanecia ainda acima do direito, com uma submissão apenas parcial. 
O enfoque ex parte populi significa a limitação jurídica do Estado e surge como reação burguesa contra o Estado de polícia. ${ }^{72} \mathrm{Na}$ França, após a revolução, surge como Etat Constitutional, que tem base na imperatividade formal da constituição e sua rigidez. No cerne, estava a necessidade de segurança inerente à produção, com base no controle da administração. ${ }^{73}$

Para o direito alemão, segundo sua jurisprudência constitucional, não há comportamento livre na administração, pois mesmo a discrição tem bases legais. ${ }^{74}$ Essa submissão da administração à lei é conteúdo do princípio do Estado Democrático de Direito. ${ }^{75}$

\subsection{Distinção entre o político e o administrativo}

Concluindo que não há mérito administrativo ou discricionariedade administrativa intocável, resta a dificuldade que o judiciário enfrenta com a ausente distinção do que vem a ser administrativo ou político. Isso se dá, sobretudo, pela divisão de poderes adotada no Brasil, que atribui unicamente ao Poder Executivo três funções distintas: a chefia do Estado, a chefia do governo e a tarefa burocrática. Ao mistifório presente no direito positivo constitucional, a jurisprudência voluntariamente se vincula, tratando, via de regra, como discricionariedade ou mérito administrativo todo e qualquer ato do Poder Executivo, sem uma discussão ontológica do próprio ato.

No direito alemão, clara está a distinção entre governo e administração, ou entre ato político e ato administrativo. Na Alemanha, a administração exerce função autônoma, cumprindo papel específico determinado pelo

72 Tratava-se também de projeto de autonomia, de auto-regulação econômica e exigências de um debate público para as questões nacionais. Era um programa revolucionário de racionalização integral do Estado segundo os interesse da sociedade. Esse processo de racionalização do Estado é indissociável do objetivo de sua limitação jurídica. O problema do Estado perante a teoria da sua personificação é decisivo na construção do Estado de Direito. 73 Segundo Paulo Modesto (Op. cit., p. 73), atualmente o controle da administração se classifica em: "A) controle interno (realizado por órgãos' integrantes de uma mesma estrutura funcional) e em controle externo (realizado por órgãos estranhos à estrutura do sujeito controlado); B) preventivo, concomitante ou sucessivo (vale dizer o controle que antecede, é contemporâneo ou posterior ao ato controlado); C) controle objetivo (dirigido a atos funcionais, verificando a sua validade jurídica) e subjetivo (dirigido aos titulares dos órgãos de atuação, como remoção, nomeação, destituição etc.); D) controle de legalidade (verificando pertinência do ato no sistema legal), de mérito (apreciando a sua conveniência e oportunidade) e, até, mais recentemente, controle da rentabilidade ou eficiência (avaliando a ralação custo-benefício da atuação administrativa em face de sua destinação e custo social como no controle de economicidade)."

74 Cf. HECK, Luís Afonso. Op. cit., p. 183.

75 Id., Ibid., p. 199. 
ordenamento constitucional. É uma função apolítica, praticada junto ao direito e relativamente independente da política. Na expressão de Hesse, $a$ administração não pode ser entendida como 'braço alargado' do governo. Ela exerce um papel preponderante na estrutura do estado de direito social. ${ }^{76}$

O célebre caso da expulsão do padre Vito Miracapillo, em 1980, evidencia o que vem a ser poder discricionário do governo. O artigo 66 da Lei $n^{\circ}$. 6.815, de 19/08/1980, que trata da expulsão de estrangeiros, determina: Caberá exclusivamente ao Presidente da República resolver sobre a conveniência e a oportunidade da expulsão ou de sua revogação. Entendeu o Supremo Tribunal Federal que:

Compete ao Presidente da República deliberar sobre a conveniência e a oportunidade dessa medida de elevado alcance político. [...] Na espécie cuidase, realmente, de ato discricionário, praticado nos limites da Lei $6.815 / 80$ (artigos 64, 65 e 106), imune à apreciação pelo poder judiciário no que toca ao juízo de valor quanto a sua justiça. ${ }^{77}$

No julgamento do habeas corpus, denegado por decisão unânime, alguns ministros, inobstante a ementa fazer referência ao alcance político da decisão, nos votos individuais, não distinguem governo de administração ou político de administrativo. ${ }^{78}$ A anacrônica miscelânea permanece mesmo sob vigência da atual constituição, havendo, todavia,uma evolução no entendimento do STF no sentido de opor à discricionariedade os direitos fundamentais, sobretudo se 0 ato gerar quadro irreversível:

A expulsão é ato discricionário do Poder Executivo. Não se admite, no entanto, ofensa à lei e falta de fundamentação. Contra o ato expulsório são possíveis recurso administrativo - pedido de reconsideração - e apelo ao Poder Judiciário. [...] Cuida o

76 Cf. HESSE, Konrad. Elementos de Direito Constitucional da República Federal da Alemanha (Grundzüge des Verfassungsrechts der Bundesrepublik Deutschland). (Trad. Luís Afonso Heck). Porto Alegre: Fabris, 1998. p. 404.

77 STF. Habeas Corpus 508/409/DF. Pleno, j. 30/10/1980. Rel. min. Djaci Falcão. DJU 28/ 11/80. (Ementa) Grifo meu.

78 In verbis: "Não cabe ao Poder Judiciário, no exercício do controle da legalidade, ultrapassar os limites da apreciação de vícios nulificantes do ato, para ir ao exame do mérito. Esse aspecto do mérito compreensivo da conveniência, da oportunidade ou da justiça da decisão administrativa, pertine ao poder discricionário, ao juízo discricionário, inabordável ao controle judicial. [...] pois estaria comprometendo o princípio da divisão de poderes" (Voto do min. Rafael Mayer); "Não tenho dúvidas que o ato administrativo de expulsão não é ato arbitrário. Ele é porém, de maneira inequívoca, ato discricionário. [...] sendo-lhe porém vedado apreciar se o ato é justo ou injusto, conveniente ou inconveniente, oportuno ou inoportuno" (min. Moreira Alves) (www.stf.gov.br). 
Judiciário apenas do exame da conformidade do ato com a legislação vigente. Não examina conveniência e a oportunidade da medida, circunscrevendo-se em matéria de direito: observância dos preceitos constitucionais legais. ${ }^{79}$

Acatada a existência de um poder discricionário, no sentido de uma imunidade jurisdicional, este seria prerrogativa do governo e não da administração.

Entretanto, como afirma Themístocles Cavalcanti, não existe no estado de direito nenhum poder absoluto e imune à apreciação de outro poder, quando mais não seja para verificar e afirmar os limites da ação discricionária, de maneira a legitimá-la. ${ }^{80}$

Na opinião de Canotilho, limitação do poder político é algo inerente ao Estado de Direito ${ }^{81}$. Nesse sentido, o direito continental tem rejeitado a hipótese de mérito inapreciável. É o que se encontra nas constituições da Alemanha (art. 19, § IV), da Itália (art. 133) e Áustria (art. 132) sob a denominação de proteção sem lacunas. Também na França, em 1962, o Conselho de Estado derrubou o mito da idéia de inapreciabilidade do ato político ao conhecer recurso contra atos do Presidente De Gaulle, praticados com base no art. 16 da Constituição francesa que concedia a ele poderes ditatoriais. ${ }^{82}$

\subsection{A discricionariedade em face dos direitos subjetivos \\ $\mathrm{O}$ art. $1^{\circ}$ da Constituição Federal} afirma que a República Federativa do Brasil se constitui Estado Democrático de Direito. A rigor, no aspecto jurídico, todo Estado é de Direito. É a teoria da bilateralidade ou autovinculação na qual, como já mencionei, o Estado se submete a um direito criado por ele próprio. A expressão consta na Constituição de Portugal como Estado de direito democrático $\left(\operatorname{art} .2^{\circ}\right)$ e da Espanha, como Estado Social e Democrático de Direito (art. $1^{\circ}$ ). Apesar da diferença meramente formal entre a nossa Constituição e a Portuguesa, que qualifica como democrático o direito e não o Estado, tal expressão trás em si mesma um significado próprio. Não representa a junção meramente formal de um adjetivo ao conceito de Estado de Direito liberal.

Resistindo à sedução de adentrar numa complexa conceituação, vale sinteticamente ressaltar que a função

79 STF. Habeas Corpus 72082/RJ. Tribunal Pleno, j. 19/04/95. Rel. min. Francisco Rezek. DJU 01/03/96. (Ementa) Grifo meu.

80 CAVALCANTI, Themístocles Brandão. Do poder discricionário. Revista do Direito Administrativo, Rio de Janeiro: n. 101, p. 1-23, jul./set. 1970, p. 11.

81 Cf. CANOTILHO, J. J. Gomes. Direito Constitucional e Teoria da Constituição. Coimbra: Almedina, 1998, p. 92ss.

82 Cf. ASSIS, Alexandre C. de. Excesso de poder e discricionariedade: Controle judicial. Revista de Direito Público, Rio de Janeiro: nº 92, p. 147-149, out-dez/1989. p. 148. 
do Estado Democrático de Direito, no conceito de José Afonso da Silva, é superar as desigualdades, instaurando um regime democrático que realize a justiça social. ${ }^{83}$ Trata-se de uma evolução do Estado liberal, mencionado na introdução, que, antes adstrito apenas à lei, agora se vincula ao princípio democrático. A nota elementar no conceito, como já asseverado, consiste nos direitos fundamentais. Toda missão do Estado Democrático de Direito passa necessariamente pela garantia dos direitos fundamentais.

$\mathrm{O}$ art. $1^{\circ}$ da Lei Fundamental alemã afirma que os direitos fundamentais vinculam legislação, poder executivo e jurisdição como direito vigente diretamente. ${ }^{84} \mathrm{~A}$ nossa constituição, sobretudo nos art. $5^{\circ}$ ao 17 , enumera tais direitos. Trata-se de direitos subjetivos que encontram sua fundamentação no próprio Estado Democrático de Direito e são formalmente consolidados pela constituição.

Direito subjetivo, em breves palavras, é a faculdade de pleitear a realização de um interesse próprio determinado pelo ordenamento jurídico. Na definição de Flóscolo da Nóbrega, tem sua gênese no ato jurídico, causa geral da aquisição de direitos. É a faculdade de agir, de adotar um determinado comportamento, em vista de um interesse garantido pelo direito objetivo. ${ }^{85}$ Ainda segundo o mesmo autor, os elementos essenciais do direito subjetivo são: o sujeito, o objeto, o interesse e a garantia. ${ }^{86}$

Retomamos, então, a definição de ato administrativo, afirmada anteriormente e que encontra base na doutrina alemã:: ${ }^{87}$ são todas aquelas ações administrativas que surtem efeito jurídico, sendo que, para surtir efeito jurídico, o ato precisa ser válido, obedecendo à forma legal e alçando o fim pretendido, devendo seguir com precisão a lei tanto na sua forma, quanto no seu conteúdo, como também na sua motivação e finalidade.

Tal definição é válida para os atos políticos (de governo) que, no nosso sistema, não se diferenciam dos atos administrativos, já que emanam de um mesmo poder. O que nos interessa, particularmente, é a necessidade ontológica do ato ser causador de efeitos jurídicos. Podemos concluir que dos atos administrativos, compreendidos

83 SILVA, José Afonso da. Curso de Direito Constitucional. 9. ed. São Paulo: Malheiros, p. 111.

84 Cf. HESSE, Konrad. Op cit., p. 275.

85 NÓBREGA, Flóscolo da. Introdução ao Direito. Rio de Janeiro: José Konfino, 1975, p. 149.

86 Sendo o sujeito, o titular do direito; o objeto, o bem protegido; a garantia, a proteção oferecida pelo direito objetivo; e, o interesse o elemento volitivo. (Id., ibid.).

87 Cf. nota 41. 
como atos do executivo, segundo nosso sistema, nascem obrigatoriamente direitos subjetivos.

Se o mérito do ato político é inapreciável, pela miscelânea presente em nosso sistema, e a imunidade também se estende ao ato exclusivamente administrativo, o inverso também é verdadeiro e prepondera. A atribuição das duas funções estatais a um único pro-tagonista possibilita estender aos atos de governo o controle judicial da administração. Independente do silogismo, o controle da discricionariedade encontra sua racionalidade no próprio Estado democrático que não admite poder ilimitado ou sem controle. Mesmo a doutrina da validez fiscal dos atos fundamentais ${ }^{88}$ encontra obstáculo na Alemanha. Hesse afirma que ela é inválida, pois não há tarefa fiscal, cujo vencimento apropriado requer uma dispensa dos direitos de liberdade. ${ }^{89}$

\subsection{A discricionariedade em face} do Princípio da Tutela e do Monopólio

O cerne do Estado Democrático de Direito está na garantia dos direitos subjetivos. Para efetivar tal proteção, a Constituição se serve de princípios formais protetores dos direitos fundamentais. Esses princípios são mecanismos que viabilizam o esforço de aproximar a contemplação normativa com a realidade fática. ${ }^{90}$

A principal técnica formal de garantia dos direitos subjetivos dá-se pelo princípio da proteção ou principio da tutela que, como ressalta a doutrina, é a garantia das garantias constitucionais. ${ }^{91}$

O direito alemão prevê um amplo controle da eficácia dos direitos fundamentais pelo judiciário, cujo controle ocorre pelo princípio da garantia da via judicial presente na alínea 4 do art. 19 da Lei Fundamental.

O Princípio da Tutela, si per si, é um direito fundamental. Ele se insurge em face de um mérito ou de uma discricionariedade inapreciável pelo judiciário. É o que prescreve o inciso XXXV do art. $5^{\circ}$ da nossa Constituição: A lei não excluirá da apreciação do Poder Judiciário lesão ou ameaça de direito. Não pode, portanto, imputar à lei a existência de uma zona livre que, escapando da legalidade, seja

88 Doutrina que diferencia o cumprimento direto de tarefas pública em formas do direito privado e de atuação fiscal propriamente dito. Na primeira hipótese, os direitos fundamentais devem vincular o poder público, na segunda, não. (Id., ibid.).

89 Id., ibid.

90 Sobre a "Distância entre a contemplação normativa dos Direitos e Garantias Fundamentais e a realidade sócio-econômica-política-cultural brasileira", Cf. FEIJÓ, Alexsandro Rabbani Aragão. Direitos fundamentais: teoria e prática na realidade brasileira. Revista do Curso de Direito da UFMA, São Luís: v. 3, n. 1., p. 5-12, jan./mar. 1999, p 10.

91 Cf. SILVA, José Afonso da. Op. cit., p. 376. 
o espaço para o arbítrio do governante ou do administrador.

O Princípio da Tutela, segundo Canotilho, assume dois aspectos: um direito de defesa ante os tribunais e contra atos dos poderes públicos; e um direito de proteção do particular através dos tribunais. ${ }^{92}$ Também chamado na Alemanha de máxima proteção ou proteção sem lacunas, manifesta-se de várias formas através de outras normas vagas. A primeira delas é a garantia da via judicial, já mencionada. ${ }^{93}$ Trata-se, por si só, de um direito fundamental de garantia de acesso aos tribunais que, na opinião de Canotilho, é um princípio estruturante do Estado de Direito (na Constituição da República Portuguesa está no art. 20). ${ }^{94}$ Vale ainda a observação do constitucionalista português de que a competência deve estar claramente estabelecida e de que o contrário representa violação do direito subjetivo de acesso aos tribunais:

Se a determinação dos caminhos judiciais for de tal modo confusa (exemplo: através de reenvios sucessivos de competências) que o particular se sinta tão desprotegido como se não houvesse via judiciária nenhuma, haverá violação do princípio do Estado de direito e do direito fundamental de acesso ao direito e à via judicial. ${ }^{95}$

A copiosa pesquisa jurisprudencial de Luís Afonso Heck revela-nos que, na Alemanha, o Princípio da Tutela estabelece vários direitos subjetivos, dentre eles o direito à audiência judicial, direito ao juiz natural e direito a um procedimento honesto (faires Verfahren). ${ }^{96}$

Contra a inapreciabilidade do mérito, levanta-se, também, o princípio do monopólio da jurisdição. O já mencionado inciso XXXV do art. $5^{\circ} \mathrm{da}$ nossa Constituição indica que a jurisdição é monopólio do Poder Judiciário. Sequer há contencioso administrativo, como constava na Constituição anterior.

No Brasil, persiste a idéia norteamericana de abstenção do judiciário na apreciação do mérito do ato administrativo, que coincide com a idéia francesa de administração forte da primeira metade do século XX. Infelizmente, o direito brasileiro não acompanha a evolução do pensamento francês que, juntamente com o restante do ocidente, já admite o controle de todo ato administrativo.

92 Cf. CANOTILHO. Op. cit., p. 451.

93 Op. cit. HESSE, Konrad. Op. cit., p. 270.

94 Op. cit., p. 447.

95 Cf. CANOTILHO. Op. cit., p. 453.

96 Cf. HECK, Luís Afonso. O tribunal Constitucional Federal e o desenvolvimento dos princípios constitucionais: Contributo para uma compreensão da Jurisdição Constitucional Federal Alemã. Porto Alegre: Fabris, 1995, p. 213-222. 
A diferença francesa, como se sabe, está na jurisdição administrativa (em sentido estrito) lá existente. Tratase de um controle efetuado pelos tribunais administrativos e o seu prestigiado Conselho e Estado que, como vimos, sequer admite discricionariedade no ato político. O fator diferencial está na independência deste órgão em relação ao poder judiciário. Na França, portanto, da mesma forma que inexiste monopólio do judiciário, não há de se falar também de arbitrariedade intitulada de discricionariedade.

Serve portanto de paradigma os modelos de Portugal, França e Alemanha, que, a partir do princípio da proteção, fortalecem seu Estado Democrático de Direto.

\section{CONCLUSÃO}

Ao Poder Judiciário, que tem o munus de dizer o Direito nos casos concretos, é concedido verdadeiro poder normativo que pode ser usado na apreciação de ato de outro poder. Tal prerrogativa não se dá por uma posição hierarquicamente superior do judiciário em face dos outros poderes, mas para firmar o império do Direito.

Mesmo no nosso ordenamento, em sua construção objetiva e jurisprudencial do controle judiciário, não devem escapar atos de outro poder que firam os interesses individuais. É o Princípio da Tutela que, a partir de 1946, é introduzido no nosso direito constitucional nos seguintes termos: " $A$ lei não poderá excluir da apreciação do Poder Judiciário qualquer lesão de direito individual" (art. 141§ $4^{\circ}$ ). Essa inovação derrogou a afastabilidade da apreciação judicial nas questões exclusivamente políticas, presente no art. 68 da constituição de 1934.

Entende parte da doutrina que o Princípio da Tutela não se aplica aos atos políticos ou de governo, como, por exemplo, a urgência e relevância de uma medida provisória (art. 62 da C.F.), ou a conveniência e a oportunidade da expulsão de um estrangeiro (art. $66 \mathrm{da}$ lei 6.815), pois seriam conceitos indeterminados cujo intérprete seria o agente político ou administrativo e não o juiz. Não aceita o princípio democrático que, por trás das idéias de mérito ou discricionariedade destes atos de governo ou políticos, se oculte a arbitrariedade, nem tampouco que o cidadão fique à mercê do poder político.

Se dos atos nascem os direitos subjetivos, a Carta de 88 atribui ao judiciário o controle da administração não apenas em prol dos interesses individuais, mas em vista do interesse comum.

Sobre a divisão dos poderes, impera o Direito e a garantia dos direitos fundamentais. 


\section{VM+ \\ editoração eletrônica}

513222.5044

vmm.ez@terra.com.br

Composto especialmente para a Editora Meridional, em Times New Roman, corpo $11 / 13,5$, sobre o papel offset $75 \mathrm{~g}$ e impresso na

\section{/AETRÓPOLLE}

www. graficametropole.com.br
comercialegraficametropole.com. br reial@graficametropole.com. br
tel./fax +55 (51) 3318.6355 


\section{Revista da \\ Faculdade de Direito UFRGS}

Av. João Pessoa, n. 80 - CEP 90.040-000 - Porto Alegre/RS - Brasil

Tel: (51) $3316.3118 / 3316.3128 / 3316.3555 / 3316.3464$

\section{REPRESENTANTES}

\section{AMAZONAS}

Travessia Editora e Livraria Ltda. - F: (92) 3633-6565

Editora Vozes Ltda. - F: (92) 3232-5777

BAHIA / SERGIPE - LDM - Livraria e Distribuidora Multicampi Ltda. -

$F:(71)$ 2101-8000

DISTRITO FEDERAL - J. Quinderé Distribuidora de Livros Ltda. - F: (61) 3347-8461 $3347-7386$

Livraria Cultura S/A - F: (61) 3410-4033

GOIÁS - Editora Vozes Ltda. - F: (62) 3225-3077

ESPIRITO SANTO - Representações Paulista Ltda. - Logos Livraria -

$\mathrm{F}:(27) 3137-2568$

MINAS GERAIS - Alpha Distribuidora de Livros Ltda. - F: (31) 3497-9179 - 3497-1939

PARÁ - Ponto e Vírgula Comércio Ltda. - F: (91) 4006-6650

PARANÁ - Aramis Chain - F: (41) 3264-3484

Berton \& Cosmo Ltda. - A Página - F: (41) 3213-5600

Editora Vozes Ltda. - F: (41) 3233-1392

PERNAMBUCO - Potylivros Distribuidora Ltda. - F: (81) 3423-1100

Livraria Cultura S/A - Paço Alfândega - F: (81)2102-4033

Editora Vozes Ltda. - F: (81) 3423-4100

RIO DE JANEIRO - Prefácio Distribuidora de Livros Ltda. - F: (21) 2508-9797

Editora Vozes Ltda. F: (21) 2533-8358

RIO GRANDE DO NORTE - Potylivros Distribuidora Ltda. - F: (84) 3211-2001

RIO GRANDE DO SUL - Multilivro Distribuidora e Livraria Ltda. - F: (51) 3223-7363 3223-6622

Livraria Cultura S/A - Bourbon Shopping Country - F: (51)3028-4033

SANTA CATARINA - Livraria Livros \& Livros Ltda. - F: (48) 3028-6244

SÃO PAULO - Batatais Comércio e Represent. de Livros Ltda. - F: (11) 3266-3097 3266-2976

Empório do Livro Editora e Livraria Ltda. - F: (11) 3255-1447 - 3151-6401

Lerlivros Distribuidora Ltda - F: (11) 3828-2423

Livraria Cultura S/A - Conjunto Nacional - F: (11) 3170-4033

Livraria Cultura S/A - Shopping Villa Lobos - F: (11) 3024-3599

TOCANTINS - S.G. Vieira - Livraria Palmas Cultural - F: (63)3215-3123 - 3225-5217

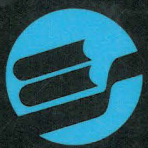

Editora Sulina

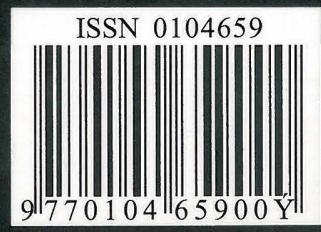

